\title{
Hepatitis, HIV and Ebola: light at the end of the tunnel.
}

\author{
James K Tumwine
}

\section{DOI: http://dx.doi.org/10.4314/ahs.v15i3.1}

Cite as: Tumwine JK. Hepatitis, HIV and Ebola: light at the end of the tunnel. Afri Health Sci. 2015;15(3): i-iv. doi: http:/ / dx.doi.org/10.4314/ahs.v15i3.1

Is African Health Sciences in danger of becoming a hepatitis journal? No, far from it! However, in this issue of African Health Sciences, we highlight the importance of hepatitis $\mathrm{B}$ and $\mathrm{C}$ from two perspectives: ancient and modern!

We highlight the articles in the current issue of AHS and reflect on the fairly old papers that give us an insight into where we have come from since 2001.

Our first choice is work from Ghana by Ephraim et $\mathrm{al}^{1}$. They report on the seroprevalence and factors associated with hepatitis B and C among pregnant women. They highlight blood transfusion, tattooing and sharing of needles as the major risk factors for Hepatitis C.

Yilmaz et al studied hepatitis B, hepatic steatosis, insulin resistance, necroinflammation and fibrosis, ${ }^{2}$ while Ogwu et $\mathrm{al}^{3}$ report on hepatitis B, C and HIV, and how they influence CD4 counts in Abeokuta, Nigeria. In a similar paper, Ogbodo and colleagues report on hepatitis $\mathrm{C}$ and HIV in the Delta state in Nigeria. ${ }^{4}$

The next four papers report on herpes simplex ${ }^{5,6}, \mathrm{HPV}^{7}$ and trypanosomiasis in $\mathrm{Gabon}^{8}$, while Yan discusses prevention of occupational skin diseases in China. ${ }^{9}$. We conclude the HIV story with HIV in Port Harcourt, ${ }^{10}$ and Candida species isolated from HIV +ve patients. ${ }^{11}$

While the Ebola epidemic rages on, Sierra Leone workers report on the use of cell phone messaging for community Ebola syndromic surveillance. ${ }^{12}$ In Zambia, Mweene-Ndumba reports on the sero-prevalence of West Nile virus. ${ }^{13}$

\section{Malaria}

The next papers deal with risk factors for placental malaria ${ }^{14}$, elimination of residual malaria transmission in Tanzania ${ }^{15}$, Artemisia annua Linn in Uganda ${ }^{16}$, and antimalarial herbs in Cameroon ${ }^{17}$ and Nigeria. ${ }^{18}$

Tuberculosis, ${ }^{19}$ MRSA, ${ }^{20}$ pneumococcal vaccine ${ }^{21}$, and tackling STIs in Ugandan communities in the $\mathrm{UK}^{22}$ is the next challenge. We end this infectious disease trea- tise with the unbelievable story of anti-bacterial properties of cows' faeces! ${ }^{23}$

\section{Non communicable diseases the next challenge}

We are then propelled into the NCDs section with papers on diabetes mellitus ${ }^{24,25,26}$, stroke ${ }^{27}$, coronary artery $^{28}, \mathrm{CVD}$ lifestyles ${ }^{29}$ and CKD-MBD in pre-dialysis patients in Nigeria ${ }^{30}$.

Then we have sickle splenomegaly ${ }^{31}$, upper GI disease ${ }^{32}$, sleep apnea ${ }^{33}$, indoor pollution ${ }^{34}$, breast cancer ${ }^{35}$, maternal and new-born nutrition ${ }^{36}$, macronutrients in Saudi Arabia $^{37}$, and the use of human urine as a plant nutrient $^{38}$. We have some interesting biochemistry of drug metabolising enzymes ${ }^{39}$, the boda boda menace ${ }^{40}$, paracetamol toxicity ${ }^{41}$, and need for anaesthesia in Sierra Leone $^{42}$.

Then a series of case reports ${ }^{43-46}$ bring us near to the end. We end with a reflection of the role of NGOs in providing curative health services in Darfur Sudan, not far off from South Sudan ${ }^{47}$ where the spectre of war remains a big worry for those of us committed to universal access to health care.

Whether the conflict in South Sudan, like elsewhere on the continent, will be resolved peacefully remains to be seen. It seems likely that the ubiquitous AK47 will remain the fear of all: much more than that of Ebola, which is beyond our reasonable control.

\section{References}

1. Ephraim R, Donko I, Sakyi SA, Ampong J, Agbodjakey H. Seroprevalence and risk factors of Hepatitis B and Hepatitis C infections among pregnant women in the Ashanti Akim North Municipality of the Ashanti region, Ghana; a cross sectional study. Afri Health Sci 2015;15(3):709-13. doi: bttp://dx.doi.org/10.4314/abs. $v 15 i 3.2$

2. Yilmaz B, Koklu S, Buyukbayram H, Yalçin K, Korkmaz U, Posul E, Can G, Kurt M. Chronic hepatitis $\mathrm{B}$ associated with hepatic steatosis, insulin resistance, necroinflammation and fibrosis. Afri Health Sci. 2015;15(3):714-8. doi: bttp://dx.doi.org/10.4314/abs. v15i3.3 
3. Ogwu-Richard SO, Ojo DA, Akingbade OA, Okonko IO. Triple positivity of HBsAg, anti-HCV antibody, and HIV and their influence on CD4+ lymphocyte levels in the highly HIV infected population of Abeokuta, Nigeria. Afri Health Sci. 2015;15(3):719-27. doi: http:// dx.doi.org/10.4314/abs.v15i3.4

4. Newton OE, Oghene OA, Okonko IO. Anti-HCV antibody among newly diagnosed HIV patients in Ughelli, a suburban area of Delta State Nigeria. Afri Health Sci. 2015;15(3):728-36. doi: bttp://dx.doi.org/10.4314/abs. $v 15 i 3.5$

5. Okonko IO, Cookey TI. Seropositivity and determinants of immunoglobulin-G (IgG) antibodies against Herpes simplex virus (HSV) types -1 and -2 in pregnant women in Port Harcourt, Nigeria. Afri Health Sci. 2015;15(3):737-47. doi: bttp://dx.doi.org/10.4314/abs. v15i3.6

6. Laaks D, Smit DP, Harvey J. Polymerase chain reaction to search for Herpes viruses in uveitic and healthy eyes: a South African perspective. Afri Health Sci. 2015;15(3):748-54. doi: bttp://dx.doi.org/10.4314/ ahs.v15i3.7

7. Broquet C, Triboullier D, Untiet S, Schafer S, Petignat P, Vassilakos P. Acceptability of self-collected vaginal samples for HPV testing in an urban and rural population of Madagascar. Afri Health Sci. 2015;15(3):755-61. doi: bttp://dx.doi.org/10.4314/abs.v15i3.8

8. Mbang Nguema OA, Mavoungou JF, Mawili-Mboumba DP, Zinga Koumba RC, Bouyou-Akotet MK, M'batchi B. Inventory of potential vectors of trypanosoma and infection rate of tsetse in the National Park of Ivindo, Gabon. Afri Health Sci. 2015;15(3):762-7. doi: bttp:/ / dx.doi.org/10.4314/abs.v15i3.9

9. Yan Y, Wang X, Wu J, Xu Li. Occupational skin diseases and prevention among sanitation workers in China. Afri Health Sci. 2015;15(3):768-75. doi: http://dx.doi. org/10.4314/abs.v15i3.10

10. Okonko IO, Nnodim LC. Trends in HIV prevalence from 2008 to 2012 among young adults in Port Harcourt, Nigeria. Afri Health Sci. 2015;15(3):776-88. doi: bttp:// dx.doi.org/10.4314/abs.v15i3.11

11.Okechukwu DC, Momoh MA, Esimone CO. Evaluation of the anti-candidal activity of methanolic leaf extract of cleistopholis patens (fam. Annonaceae) on candida species isolated from stage II HIV patients. Afri Health Sci. 2015;15(3):789-96. doi: bttp://dx.doi. org/10.4314/abs.v15i3.12

12. Jia K, Mohamed K. Evaluating the use of cell phone messaging for community Ebola syndromic surveillance in high risked settings in Southern Sierra Leone. Afri Health Sci. 2015;15(3):797-802. doi: http:/ / dx.doi. org/10.4314/abs.v15i3.13
13. Mweene-Ndumba I, Siziya S, Monze M, Mazaba ML, Masaninga F, Songolo P, Mwaba P, Babaniyi OA. Seroprevalence of West Nile Virus specific IgG and IgM antibodies in North-Western and Western provinces of Zambia. Afri Health Sci. 2015;15(3):803-9. doi: bttp:// dx.doi.org/10.4314/abs.v15i3.14

14. Ndeserua R, Juma A, Mosha D, Chilongola J. Risk factors for placental malaria and associated adverse pregnancy outcomes in Rufiji, Tanzania: a hospital based cross sectional study. Afri Health Sci. 2015;15(3):810-8. doi: http://dx.doi.org/10.4314/abs.v15i3.15

15. Semakula HM, Song G, Zhang S, Achuu SP. Potential of household environmental resources and practices in eliminating residual malaria transmission: a case study of Tanzania, Burundi, Malawi and Liberia. Afri Health Sci. 2015;15(3):819-27. doi: http://dx.doi. org/10.4314/abs.v15i3.16

16. Engeu PO, Omujal F, Agwaya M, Kyakulaga H, Obua C. Variations in antimalarial components of Artemisia annua Linn from three regions of Uganda. Afri Health Sci. 2015;15(3):828-34. doi: http://dx.doi. org/10.4314/abs.v15i3.17

17. Azebaze AGB, Teinkela JEM, Nguemfo EL, Valentin A, Dongmo AB, Vardamides JC. Antiplasmodial activity of some phenolic compounds from Cameroonians Allanblackia. Afri Health Sci. 2015;15(3):83540. doi: http:/ / dx.doi.org/10.4314/abs.v15i3.18

18. Oyinloye OE, Kosoko AM, Emikpe B, Falade CO, Ademowo OG. Potential antimalarial activity of Methyl Jasmonate and its effect on lipid profiles in Plasmodium Berghei infected mice. Afri Health Sci. 2015;15(3):84150. doi: http:/ / dx.doi.org/10.4314/abs.v15i3.19

19. Mumpe-Mwanja D, Verver S, Yeka A, Etwom A, Waako J, Ssengooba W, Matovu JKB, Wanyenze RK, Musoke P, Mayanja-Kizza H. Prevalence and predictors of latent Tuberculosis among adolescents in rural Eastern Uganda. Afri Health Sci. 2015;15(3):851- 60. doi: bttp:/ / dx.doi.org/10.4314/abs.v15i3.20

20. Mahmoud AM, Albadawy HS, Bolis SM, Bilal NE, Ahmed AO, Ibrahim ME. Inducible clindamycin resistance and nasal carriage rates of Staphylococcus aureus among healthcare workers and community members. Afri Health Sci. 2015;15(3):861-7. doi: bttp://dx.doi. org/10.4314/abs.v15i3.21

21. Torres-Rueda S, Burchett HED, Griffiths UK, Ongolo-Zogo P, Edengue J-M, Kitaw Y, Molla M, Gelmon L, Onyango-Ouma W, Konate M, Mounier-Jack S. New pneumococcal conjugate vaccine introduction in four sub-Saharan African countries: a cross-country analysis of health systems' impacts. Afri Health Sci. 2015;15(3):868-77. doi: bttp://dx.doi.org/10.4314/abs. v15i3.22 
22. Atukunda EC, Mugyenyi GR, Oloro J, Hughes S. Tackling sexually transmitted infection burden in Ugandan communities living in the United Kingdom: a qualitative analysis of the socio-cultural interpretation of disease and condom use. Afri Health Sci. 2015;15(3):87887. doi: bttp:// dx.doi.org/10.4314/abs.v15i3.23

23. Adeniyi BA, Adetoye A, Ayeni FA. Antibacterial activities of lactic acid bacteria isolated from cow faeces against potential enteric pathogens. Afri Health Sci. 2015;15 (3):888-95. doi: bttp://dx.doi.org/10.4314/abs. v15i3.24

24. Al-Shreef FM, Al-Jiffri OH, Abd El-Kader SM. Bone metabolism and hand grip strength response to aerobic versus resistance exercise training in non-insulin dependent diabetic patients. Afri Health Sci. 2015;15(3):896-901. doi: http://dx.doi.org/10.4314/ahs. v15i3.25

25. Tanyanyiwa D, Dandara C, Bhana SA, Pauly B, Marule F, Ramokoka M, Bwititi P, Nwose U, Nkosi B. Implementation of POCT in the diabetic clinic in a large hospital. Afri Health Sci. 2015;15(3):902-7. doi: bttp:/ / dx.doi.org/10.4314/abs.v15i3.26

26. Nkeh-Chungag BN, Mxhosa TH, Mgoduka PN. Association of waist and hip circumferences with the presence of hypertension and pre-hypertension in young South African adults. Afri Health Sci. 2015 15(3):908-16. doi: bttp:/ / dx.doi.org/10.4314/abs.v15i3.27 27. Urimubenshi G. Activity limitations and participation restrictions experienced by people with stroke in Musanze district in Rwanda. Afri Health Sci. 2015;15(3):917-24. doi: bttp://dx.doi.org/10.4314/abs. v15i3.28

28. Aykut A, Bumin D, Omer Y, Mustafa K, Meltem C, Orhan C, Nisa U, Hikmet O, Hakan D, Mert K. The comparison of high and standard definition computed tomography techniques regarding coronary artery imaging. Afri Health Sci. 2015;15(3):925-30. doi: http:/ / dx.doi.org/10.4314/abs.v15i3.29

29. Nse O, Quinette L, Okechukwu O. A systematic review and appraisal of methods of developing and validating lifestyle cardiovascular disease risk factors questionnaires. Afri Health Sci. 2015;15(3):931-40. doi: http:/ / dx.doi.org/10.4314/abs. v15i3.3

30. Okoye JU, Arodiwe EB, Ulasi II, Ijoma CK, Onodugo OD. Prevalence of CKD-MBD in pre-dialysis patients using biochemical markers in Enugu, South-East Nigeria. Afri Health Sci. 2015;15(3):941-8. doi: http:// dx. doi.org/10.4314/abs.v15i3.31

31. Eze CU, Offordile GC, Agwuna KK, Ocheni S, Nwadike IU, Chukwu BF. Sonographic evaluation of the spleen among sickle cell disease patients in a teach- ing hospital in Nigeria. Afri Health Sci. 2015;15(3):94958. doi: http:// dx.doi.org/10.4314/ahs.v15i3.32

32. Obayo S, Muzoora C, Ocama P, Cooney MM, Wilson T, Probert CS. Upper gastrointestinal diseases in patients for endoscopy in South-Western Uganda. Afri Health Sci. 2015;15(3):959-66. doi: bttp://dx.doi. org/10.4314/abs.v15i3.33

33. James BO, Inogbo CF, Archibong AO. Risk of obstructive sleep apnoea syndrome among in-patients at a neuropsychiatric hospital in Nigeria: a short report. Afri Health Sci. 2015;15(3):967-71. doi: http://dx.doi. org/10.4314/abs.v15i3.34

34. Majdan M, Svaro M, Bodo J, Taylor M, Muendo RM. Assessment of the biomass related indoor air pollution in Kwale district in Kenya using short term monitoring. Afri Health Sci. 2015;15(3):972-81. doi: bttp:/ / dx.doi.org/10.4314/abs.v15i3.35

35. Cao Z-G, Qin X-B, Liu F-F, Zhou L-L. Tryptophan-induced pathogenesis of breast cancer. Afri Health Sci. 2015;15(3):982-5. doi: http://dx.doi.org/10.4314/abs. v15i3.36

36. Ugwuja EI, Nnabu RC, Ezeonu PO, Uro-Chukwu $H$. The effect of parity on maternal body mass index, plasma mineral element status and new-born anthropometrics. Afri Health Sci. 2015;15(3):986-92. doi: http:/ / dx.doi.org/10.4314/ahs.v15i3.37

37. Huwait EA, Kumosani TA, Moselhy SS, Masawi RM, Yaghmour SS. Relationship between soil cobalt and vitamin B12 levels in the liver of livestock in Saudi Arabia: role of competing elements in soils. Afri Health Sci. 2015;15(3):993-8. doi: bttp://dx.doi.org/10.4314/ abs. v15i3.38

38. Mugivhisa LL, Olowoyo JO. An assessment of university students and staff perceptions regarding the use of human urine as a valuable plant nutrient in South Africa. Afri Health Sci. 2015;15(3):999-1010. doi: bttp:/ / dx.doi.org/10.4314/abs.v15i3.39

39. Xiao W, Lu M-H. Comparison of the inhibition capability of oleanolic acid and betulinic acid towards drug-metabolizing enzymes. Afri Health Sci. 2015;15(3):1011-5. doi: bttp://dx.doi.org/10.4314/abs. v15i3.40

40. Kamulegeya LH, Kizito M, Nassali R, Bagayana S, Elobu AE. The scourge of head injury among commercial motorcycle riders in Kampala; a preventable clinical and public health menace. Afri Health Sci. 2015;15(3):1016-22. doi: bttp://dx.doi.org/10.4314/abs. v15i3.41.

41. Yang H, Jiang T, Li P, Mao Q. The protection of glycyrrhetinic acid (GA) towards acetaminophen (APAP)-induced toxicity partially through fatty acids 
metabolic pathway. Afri Health Sci. 2015;15(3):1023-7. doi: http://dx.doi.org/10.4314/abs.v15i3.42

42. Harris MJ, Kamara TB, Hanciles E, Newberry C, Junkins SR, Pace NL. Assessing unmet anaesthesia need in Sierra Leone: a secondary analysis of a cluster-randomized, cross-sectional, countrywide survey. Afri Health Sci. 2015;15(3):1028-33. doi: http://dx.doi. org/10.4314/ ahs.v15i3.43

43. Ocaya A. Retroesophageal right subclavian artery: a case report and review of the literature. Afri Health Sci. 2015;15(3):1034-7. doi: bttp://dx.doi.org/10.4314/ ahs.v15i3.44

44. Meel Banwari L. A case report on near manual strangulation and glasgow coma scale. Afri Health Sci.
2015;15(3):1038-40. doi: bttp://dx.doi.org/10.4314/ahs. v15i3.45

45.Katibi OS, Adepoju FG, Olorunsola BO, Ernest SK, Monsudi KF. Blindness and scalp haematoma in a child following a snakebite. Afri Health Sci. 2015;15(3):1041-4. doi: bttp:/ / dx.doi.org/10.4314/ahs.v15i3.46

46. Deepak M, Basavaprabhu A, Soundarya M. Multiple intracerebral lesions in a young male. Afri Health Sci. 2015;15(3):1045-8. doi: http://dx.doi.org/10.4314/ahs. $v 15 i 3.47$

47. Yagub AIA, Mtshali K. The role of non-governmental organizations in providing curative health services in North Darfur State, Sudan. Afri Health Sci. 2015;15(3):1049-55. doi: http://dx.doi.org/10.4314/ahs. v15i3.48 